\title{
Anti-tumour necrosis factor $\alpha$ therapy - Does it increase the risk of thyroid disease or protect against its development?
}

Terapia z zastosowaniem przeciwciał przeciwko czynnikowi martwicy nowotworów $\alpha$ - zwiększa ryzyko chorób tarczycy czy chroni przed ich rozwojem?

\author{
Aleksandra Furtak, Anna Wedrychowicz, Jerzy Starzyk
}

Institute of Paediatrics, Department of Children and Youth Endocrinology, Jagiellonian University Medical College, Krakow, Poland

\begin{abstract}
Aim of the study: Tumour necrosis factor $\alpha$ (TNF- $\alpha$ ) is a cytokine involved in the pathogenesis of many diseases, primarily those associated with autoimmunisation. Anti-TNF- $\alpha$ drugs are used in the therapy of many of them, such as rheumatoid arthritis, psoriatic arthritis, ankylosing spondylitis, psoriasis, or inflammatory bowel disease. TNF- $\alpha$ is also a key factor in the pathogenesis of autoimmune thyroid disease (AITD). The incidence of AITD in people with other autoimmune diseases is increased compared to the general population. Therefore, it would be interesting to find out if anti-TNF- $\alpha$ therapy of other autoimmune diseases could influence the possible development or regression of thyroid gland dysfunction, especially AITD.

Aim of the study: The main aim of the study is to assess the effect of anti-TNF- $\alpha$ therapy used in inflammatory and immunological diseases on thyroid function and the development of AITD.

Conclusions: The real impact of anti-TNF- $\alpha$ therapy on the development of AITD remains an open question. The available studies concern the adult population; there are no data regarding this problem in children. Due to the increasing use of anti-TNF- $\alpha$ therapy also in the paediatric population, it seems reasonable to evaluate this subject in this group of patients.

Key words:

TNF- $\alpha$, anti-TNF- $\alpha$ therapy, autoimmunisation, AITD.

Streszczenie

Wprowadzenie: Czynnik martwicy nowotworów $\alpha$ (tumor necrosis factor $\alpha$-TNF- $\alpha$ ) to cytokina biorąca udział w patogenezie wielu chorób, przede wszystkim tych, które rozwijają się na podłożu autoimmunizacji. W terapii wielu z nich, takich jak reumatoidalne zapalenie stawów, łuszczycowe zapalenie stawów, zesztywniające zapalenie stawów kręgosłupa, łuszczyca czy nieswoiste choroby zapalne jelit, stosowane są leki określane mianem anty-TNF- $\alpha$. Czynnik martwicy nowotworów $\alpha$ jest także kluczowym czynnikiem biorącym udział w patogenezie autoimmunizacyjnej choroby tarczycy.

Częstość występowania autoimmunizacyjnej choroby tarczycy u osób chorujących na wyżej wymienione choroby jest zwiększona w porównaniu z populacją ogólną. Stwarza to pytanie o wpływ terapii anty-TNF- $\alpha$ na ewentualny rozwój zaburzeń czynności i morfologii gruczołu tarczowego, w tym szczególnie autoimmunizacyjnej choroby tarczycy.

Cel pracy: Głównym celem pracy jest ocena wpływu terapii anty-TNF- $\alpha$, stosowanej w chorobach zapalnych i immunologicznych, na czynność tarczycy i rozwój autoimmunizacyjnej choroby tarczycy.

Wnioski: Pytanie o wpływ terapii anty-TNF- $\alpha$ na rozwój autoimmunizacyjnej choroby tarczycy wciąż pozostaje bez konkretnej odpowiedzi. Ponadto dostępne badania dotyczą populacji osób dorosłych. Z uwagi na coraz szersze zastosowanie terapii anty-TNF- $\alpha$ także w populacji pediatrycznej, zasadne wydaje się objęcie badaniami także tej grupy pacjentów.
\end{abstract}

Słowa kluczowe:

TNF- $\alpha$, terapia anty-TNF- $\alpha$, autoimmunizacja, AITD. 


\section{Introduction}

Tumour necrosis factor $\alpha$ is an important cytokine of inflammatory and immunological reactions, it is involved in the pathogenesis of many diseases, including autoimmune diseases $[1,2]$. This fact has become the basis for the search for new therapeutic options for patients suffering from diseases such as rheumatoid arthritis, psoriatic arthritis, ankylosing spondylitis, psoriasis, or inflammatory bowel diseases. Hence, anti-TNF- $\alpha$ drugs were created, the main task of which is to reduce the concentration of TNF- $\alpha$ and thereby inhibit the cascade of phenomena occurring in the course of its action, which can lead to the development of the disease. TNF- $\alpha$ is also a key factor involved in the pathogenesis of thyroid disease, including AITD.

As is known from the available literature, the incidence of AITD in people with other autoimmune diseases, such as rheumatoid arthritis or inflammatory bowel disease, is increased compared to the general population. Therefore, it would be interesting to know if anti-TNF- $\alpha$ therapy of other autoimmune diseases could have an influence on possible development or regression of thyroid gland dysfunction, especially AITD.

\section{Aim of the study}

The main aim of the study is to assess the effect of antiTNF- $\alpha$ therapy used in inflammatory and autoimmunological diseases on thyroid function and the development of AITD.

\section{Discussion}

TNF- $\alpha$, described for the first time by Carswell et al. in 1975, also known as cachectin, is an important cytokine of inflammatory and immunological reactions $[1,2]$. The TNF- $\alpha$ gene, located on chromosome 6p21.3, consists of four exons, and its promoter region shows very high variability, which determines the differentiated cytokine secretion in individuals [1]. Active TNF- $\alpha$ consists of three polypeptide chains, and it is formed as a result of a metalloproteinase (TNF- $\alpha$-converting enzyme) action on its precursor synthesised as a transmembrane protein. TNF- $\alpha$ is mainly produced by monocytes and macrophages. Its source can also be lymphocytes, mast cells, fibroblasts, keratinocytes, endothelial cells, cardiomyocytes, or thyroid cells [1, 3-5].

The main stimulators of TNF- $\alpha$ production are lipopolysaccharides (LPS) of bacterial cell wall. In addition, TNF- $\alpha$ synthesis is stimulated by other cytokines such as INF- $\alpha$ and IL-1. Also, TNF- $\alpha$ in an autocrine manner stimulates its own synthesis. Glucocorticosteroids, IL-4, IL-10, and PGE2 are inhibitors of TNF- $\alpha$ production $[1,6]$.

TNF- $\alpha$ has affinity for two types of receptors: TNF-R1 (CD120a, p55 / 60) and TNF-R2 (CD120b, p75/80). They both, in their intracellular part, contain a so-called death domain. TNF-R 1 is activated by both free and transmembrane forms of TNF- $\alpha$. TNF-R2 binds mainly to transmembrane forms of TNF- $\alpha$. $\mathrm{TNF}-\alpha$ receptors also differ in their location: TNF-R1 is located on nuclear cells, and TNF-R2 on immune cells, fibroblasts, and endothelial cells. In addition, expression of TNF- $\alpha$ receptors is increased by interleukin 1 (IL-1), interferon $\gamma(\mathrm{INF}-\gamma)$, IL-2, and TNF- $\alpha$ alone [1]. After binding of TNF- $\alpha$ to the TNF-R1 receptor, the protein inhibitor SODD (silencer of death domain) is disconnected from the intracellular death domain, which allows activation of the TRADD protein (TNF-R-associated death domain) and further signal transduction steps. These stages can be carried out in three ways, depending on the connection of TRADD with subsequent relays. As a result of the attachment to the TNFR1-TRADD of the FADD (Fas-associated death domain) adapter protein, the caspase cascade (mainly $8,3,7$ ) is activated, which ultimately leads to cell apoptosis [7]. As a result of the attachment to TNFR1-TRADD of RIP (receptor-interacting protein) and/or TRAF2 (TNF receptor-associated factor 2) transmitters, a cascade of kinases is activated, including the $\kappa \mathrm{B}$ inhibitor kinase $\left(\left.\right|_{\kappa} B\right)$, which is released by phosphorylation of $\left.\right|_{\kappa} B N F-\kappa B$ cytoplasm, and its further activities at the level of the cell nucleus primarily lead to cell activation and prevent apoptosis [7]. The third way is through attachment to the TNFR1-TRADD of the TRAF2 adapter protein and the activation of the MEKK1 (Mitogen activated protein kinase/ERK kinase 1) system, which induces the so-called JNK trail (c-Jun N-terminal kinase). The JNK pathway usually leads, through the transcription factor AP-1, to cell stimulation and proliferation. However, there is also evidence of a proapoptotic effect of JNK pathway activation [8].

$\mathrm{TNF}-\alpha$ is an extremely powerful mediator of inflammatory and immunological reactions. It can act independently or in combination with a wide range of other cytokines, affecting almost all cells in the body. TNF- $\alpha$ increases the cytotoxicity and phagocytic properties of cells of the immune system, it affects the proliferation and differentiation of B lymphocytes, T Iymphocytes, and NK cells, and increases the synthesis of cytokines. In addition, it induces the expression of MHC I, MHC II, and adhesive particles and chemokines necessary for the accumulation of immune cells at the site of inflammation [1].

The indisputable influence of TNF- $\alpha$ on the immune system makes it a key factor in the pathogenesis of many diseases, including autoimmune diseases. This fact has become the basis for seeking new therapeutic options for patients suffering from diseases such as rheumatoid arthritis, psoriatic arthritis, ankylosing spondylitis, psoriasis, or inflammatory bowel diseases. As a consequence of the knowledge of this phenomenon, antiTNF- $\alpha$ drugs were created, the main task of which is to directly reduce the concentration of TNF- $\alpha$ and thereby inhibit the cascade of phenomena occurring in the course of its action.

TNF- $\alpha$ inhibitors are monoclonal antibodies, antibody fragments, or fusion proteins. This group of biological drugs includes the following: infliximab (IFX), which is a monoclonal, chimeric, human-mouse (75\%: 25\% protein structure) IgG1class antibody with a molecular weight of $149 \mathrm{kDa}$; adalimumab (ADA), which is a purely human class antibody; IgG1 with a molecular weight of $148 \mathrm{kDa}$; certolizumab (CER), which is a humanised Fab fragment (approximately 90\% human) of polyethylene glycol conjugated monoclonal antibody (PEG); and etanercept (ETA), which is a fusion protein composed of 
the extracellular portion of the TNFR2/p75 receptor (this portion binds TNF- $\alpha$ ) fused to the lgG1 Fc fragment [9].

TNF- $\alpha$ is also involved in the pathogenesis of thyroid dysfunction, including AITD. As many authors report, the concentration of TNF- $\alpha$ and TNF- $\alpha$ mRNA in the thyroid tissue in people with AITD and other thyroid gland disorders is definitely higher compared to people without those disorders. Thyroid infiltrating lymphocytes are a reliable source of TNF- $\alpha$; moreover, TNF- $\alpha$ production by thyroid cells alone has been reported. Zheng et al. [5] proved that thyroid cells are capable of producing TNF- $\alpha$; Grubeck-Loebenstein et al. [10] did not show the presence of TNF- $\alpha$ mRNA in thyroid cells; and Diez et al. [4] showed an increased concentration of TNF- $\alpha$ in the thyroid tissue of people with AITD, but they did not specify its source (lymphocytes or thyreocytes). Thyroid cells have receptors for TNF- $\alpha$ on their surface, and it is postulated that TNF- $\alpha$ plays an essential role in cytotoxic mechanisms leading to the destruction of thyroid tissue in AITD [4]. This cytokine is responsible for the increase in the expression of $\mathrm{MHC}$ class I molecules on thyroid cells in Graves' disease and, together with INF- $\gamma$, for the increase in MHC class II expression $[11,12]$. TNF- $\alpha$ has been shown to increase IL-6 production by thyroid cells [13]. TNF- $\alpha$ affects the tightness of thyreocyte epithelium, which leads to a loss of its barrier function and an increase in the access of immune cells to intravesical antigens [14, 15]. In addition, TNF- $\alpha$ inhibits the production of thyroglobulin [16], reduces TSH-induced iodine uptake by thyroid cells [17], reduces type 2 deiodinase activity, which leads to a decrease in peripheral production of triiodothyronine from thyroxine, and also reduces autocrine production of triiodothyronine in the thyroid alone $[18,19]$. TNF- $\alpha$ also influences the function of the hypothalamus-pituitary-thyroid axis. TNF- $\alpha$ inhibits TRH, which reduces the secretion of TSH [20]. The mechanisms described above are also involved in the pathogenesis of low T3 syndrome (euthyroid sick syndrome), which may accompany severe chronic diseases for which an increase in TNF- $\alpha$ is typical [20].

Due to the fact that diseases in which anti-TNF- $\alpha$ therapy is used are associated with a higher risk of developing AITD compared to the general population [21, 22] and that TNF- $\alpha$ plays a role in the aetiopathogenesis of thyroid dysfunction, one would expect that anti-TNF- $\alpha$ therapy would have a protective effect against the possible development of AITD, and would be therapeutic if it is present.

There are few reports in the available literature about the development of thyroid dysfunction during anti-TNF- $\alpha$ therapy. In addition, it provides very diverse data (Table I). Cerniglia et al. reported the development of hypothyroidism in a 47-year-old patient treated with infliximab for sarcoidosis. The ultrasound image of the thyroid gland corresponded to autoimmune thyroid disease. The authors postulated that the cause of AITD in the patient was the formation of autoantibodies (against infliximab) that induced autoimmune thyroiditis [23]. Lahita et al. described a 55-year-old patient who developed autoimmune thyroiditis during long-term anti-TNF- $\alpha$ therapy for psoriatic arthritis. Based on elevated TSH levels before starting anti-TNF- $\alpha$ therapy, the authors suggested that autoimmune thyroiditis may have occurred before treatment. Nonetheless, anti-TNF- $\alpha$ therapy led to the progression of autoimmune thyroiditis [24]. Van Lieshout et al. are the authors of a report on the development of Graves' disease in a patient treated with anti-TNF- $\alpha$ for rheumatoid arthritis [25]. Similarly, Allanore et al. reported a transient hyperthyroidism lasting one month in a patient after six months of treatment with etanercept [26]. Caramaschi et al. described a group of 54 patients with rheumatoid arthritis, among whom six changed the titre of anti-thyroid peroxidase antibodies (ATPO) or anti-thyroglobulin antibodies (aTG) from negative to positive, and four from positive to negative, after 12 months of therapy with infliximab or etanercept [27]. Atzeni et al., in a study of 20 patients (including six with positive ATPO and eight with positive aTG) with rheumatoid arthritis, showed a change in ATPO from positive to negative in one of the patients after six months of treatment with adalimumab [28]. Pascart et al. examining patients treated with anti-TNF- $\alpha$ due to rheumatological diseases in their centre, described 11 cases of development of AITD, including six cases of Graves' disease, three cases of Hashimoto's disease, and two cases of subacute thyroiditis [29]. Raterman et al., in a group of 138 patients with rheumatoid arthritis, after six months of treatment with adalimumab, described a change in the ATPO titre from positive to negative in one of 21 patients with a positive ATPO at baseline. They also indicated a lower average ATPO concentration after therapy (267 to $201 \mathrm{IU} / \mathrm{ml})$. In addition, two patients with hypothyroidism reported a return to euthyroidism. They also showed a decrease in TSH (from $12.5 \mathrm{mU} / \mathrm{l}$ [6.7-18.4] to $7.1 \mathrm{mU} / \mathrm{l}$ [4.9-13.8]) in patients with hypothyreosis, who were ATPO positive and not receiving levothyroxine [30]. Elkayam et al., in a study group of 26 patients with rheumatoid arthritis, described a negative ATPO titre in all patients before and after 14 weeks of treatment with infliximab [31]. Tarhan et al., in a study of 108 patients with ankylosing arthritis spine (44 received anti-TNF- $\alpha, 64$ received other drugs), reported a positive ATPO titre in 23 patients not treated with anti-TNF- $\alpha$ (mean ATPO $86.69 \pm 65.28 \mathrm{U} / \mathrm{ml})$, compared to nine patients receiving antiTNF- $\alpha$ (mean TPO $36.61 \pm 14.02 \mathrm{U} / \mathrm{ml}$ ) [32]. Paschou et al. studied a group of 41 patients ( 18 treated with anti-TNF- $\alpha, 12$ treated with other drugs followed by anti-TNF- $\alpha, 11$ treated only with other drugs) with Crohn's disease or ulcerative enteritis. They found overt or subclinical hyperthyroidism in two patients in the untreated anti-TNF- $\alpha$ group and no thyroid dysfunction or AITD in patients receiving anti-TNF- $\alpha$. In addition, they showed the presence of thyroid antibodies in $5.6 \%$ of patients treated with anti-TNF- $\alpha$ and in $17.4 \%$ of those treated with other drugs [33].

Analysing the impact of anti-TNF- $\alpha$ therapy on thyroid function and the development of autoimmune thyroid disease, it is also worth paying attention to the role of TNF- $\alpha$ and anti-TNF- $\alpha$ therapy in thyroid-associated ophthalmopathy (TAO). According to the data, TNF- $\alpha$ is involved in the pathogenesis of TAO [34]. For this reason, anti-TNF- $\alpha$ therapy is increasingly being used to treat TAO. Paridaens et al., in their pilot study, presented 10 patients with mild to moderate Graves' ophthalmopathy treated with etanercept for 12 weeks. In this study, $60 \%$ of patients had moderate to marked improvement of TAO after this 
Table I. Effect of anti-TNF- $\alpha$ therapy on thyroid function - summary of available publications

The negative effect of anti-TNF- $\alpha$ therapy used in inflammatory and immunological diseases on thyroid function and the development of AITD

\section{Cerniglia et al. 2013 [23]}

development of hypothyroidism in a 47-year-old patient treated with antiTNF- $\alpha$ therapy for sarcoidosis

Lahita et al. 2011 [24]

progression of autoimmune thyroiditis in a 55-year-old patient during long-term anti-TNF- $\alpha$ therapy for psoriatic arthritis
The positive effect of anti-TNF- $\alpha$ therapy used in inflammatory and immunological diseases on thyroid function and the development of AITD

\section{Caramaschi et al. 2006 [27]}

changed the titre of ATPO or aTG from positive to negative, after 12 months of therapy with anti TNF- $\alpha$ for rheumatoid arthritis in four patients from group of 54 patients
The neutral effect of anti-TNF- $\alpha$ therapy used in inflammatory and immunological diseases on thyroid function and the development of AITD

Elkayam et al. 2005 [31] negative ATPO titre in all 26 patients before and after 14 weeks of treatment with antiTNF- $\alpha$ for rheumatoid arthritis

Raterman et al. 2011 [30]

change in the ATPO titre from positive to negative in one of 21 patients in a group of 138 patients with rheumatoid arthritis after 6 months of treatment with anti TNF- $\alpha$ lower average ATPO concentration after therapy (267 to $201 \mathrm{lU} / \mathrm{ml}$ ) two patients with hypothyroidism reported a return to euthyroidism decrease in TSH (from $12.5 \mathrm{mU} / \mathrm{l}(6.7-18.4)$ to $7.1 \mathrm{mU} / \mathrm{l}$ [4.9-13.8]) in patients with hypothyreosis, ATPO positive, and not receiving levothyroxine

Van Lieshout et al. 2008 [25] development of Graves' disease in a patient treated with anti TNF- $\alpha$ for rheumatoid arthritis
Tarhan et al. 2013 [32]

positive ATPO titre in 9 patients receiving anti-TNF- $\alpha$ (mean ATPO $36.61 \pm 14.02 \mathrm{U} / \mathrm{ml}$ ) compared to 23 patients not treated with anti TNF- $\alpha$ (mean ATPO $86.69 \pm 65.28 \mathrm{U} / \mathrm{ml}$ ) due to ankylosing arthritis spine (44 received antiTNF- $\alpha, 64$ other drugs)

Paschou et al. 2018 [33]

no thyroid dysfunction or AITD in patients receiving anti-TNF- $\alpha$ compared to development overt or subclinical hyperthyroidism in two patients in the untreated anti-TNF- $\alpha$ group of 41 patients (18 treated with anti TNF- $\alpha$; 12 treated with other drugs followed by anti TNF- $\alpha$; 11 treated only with other drugs) with Crohn's disease or ulcerative enteritis presence of thyroid antibodies in $5.6 \%$ of patients treated with anti-TNF- $\alpha$ and in $17.4 \%$ treated with other drugs.

Caramaschi et al. 2006 [27]

changed the titre of ATPO or aTG from negative to positive, after 12 months of therapy with anti-TNF- $\alpha$ for rheumatoid arthritis in 6 patients from a group of 54 patients 
Table I. Effect of anti-TNF- $\alpha$ therapy on thyroid function - summary of available publications (cont.)

The negative effect of anti-TNF- $\alpha$ therapy used in inflammatory and immunological diseases on thyroid function and the development of AITD
The positive effect of anti-TNF- $\alpha$ therapy used in inflammatory and immunological diseases on thyroid function and the development of AITD
The neutral effect of anti-TNF- $\alpha$ therapy used in inflammatory and immunological diseases on thyroid function and the development of AITD

Pascart et al. 2014 [29]

development of thyroid diseases in 11 patients (six cases of Graves' disease, three cases of Hashimoto's disease and two cases of subacute thyroiditis) treated with anti-TNF- $\alpha$ due to rheumatological diseases

anti-TNF- $\alpha$ - anti-tumour necrosis factor $\alpha$; AITD - autoimmune thyroid disease; ATPO - anti-thyroid peroxidase antibodies; aTG - anti-thyroglobulin antibodies; TSH - thyroid-stimulating hormone

treatment [35]. Boskovic et al. presented a female patient with both Graves' ophthalmopathy and rheumatoid arthritis, who was treated with etanercept. This treatment led to an improvement of eye symptoms [36]. Komorowski et al. found a positive effect of Infliximab administration on active TAO in a 58-yearold woman with Graves' disease [37]. These findings suggest that anti-TNF- $\alpha$ therapy may benefit patients with TAO, but all of the mentioned authors point out the necessity of larger studies to confirm its efficacy and safety [38].

\section{Conclusions}

Research on biological anti-TNF- $\alpha$ drugs dates back to the 1990s. According to the cited data, despite the relatively long observation time, the question about the impact of anti-TNF- $\alpha$

\section{References}

1. Lubecka-Macura A, Kohut M. TNF superfamily - mechanisms of action, biologic functions and therapeutic possibilities. Gastroenterology Rev 2010; 5: 303-309. doi: 10.5114/pg.2010.18472

2. Korobowicz A. Biologia czynnika martwicy nowotworów typu alfa (TNF alfa). Pol Merk Lek 2006; 124: 358-361.

3. Aust G, Heuer M, Laue $S$, et al. Expression of tumour necrosis factor-alpha (TNF-alpha) mRNA and protein in pathological thyroid tissue and carcinoma cell lines. Clin Exp Immunol 1996; 105 : 148-154. doi:10.1046/j.1365-2249.1996.d01-726.x

4. Díez JJ, Hernanz A, Medina S, et al. Serum concentrations of tumour necrosis factor-alpha (TNF-alpha) and soluble TNF-alpha receptor p55 in patients with hypothyroidism and hyperthyroidism therapy on the development or regression of AITD remains open. In addition, according to our knowledge, all available studies concern the adult population. Due to the increasing use of anti-TNF- $\alpha$ therapy also in the paediatric population, it seems reasonable to evaluate this group of patients regarding this subject.

In our clinical centre, anti-TNF- $\alpha$ treatment of children and adolescents with inflammatory bowel diseases is carried out. We are currently in the process of investigating the effect of anti-TNF- $\alpha$ therapy on thyroid gland function and morphology in children and adolescents with Crohn's disease treated with infliximab. The first preliminary results are promising. They indicate that anti-TNF- $\alpha$ treatment may reduce the incidence of AITD in paediatric patients with Crohn's disease compared to non-biological patients. before and after normalization of thyroid function. Clin Endocrinol (Oxf) 2002; 57: 515-521.

5. Zheng RQ, Abney ER, Chu CQ, et al. Detection of in vivo production of tumour necrosis factor-alpha by human thyroid epithelial cells. Immunology 1992; 75: 456-462.

6. Hehlgans T, Pfeffer K. The intriguing biology of the tumour necrosis factor/tumour necrosis factor receptor superfamily: players, rules and the games. Immunology 2005; 115: 1-20. doi:10.1111/j.13652567.2005.02143.x

7. Gupta S. A decision between life and death during TNF-alphainduced signaling. J Clin Immunol 2005; 22: 185-194.

8. Haeusgen W, Herdegen T, Waetzig V. The bottleneck of JNK signaling: molecular and functional characteristics of MKK4 and MKK7. Eur J Cell Biol 2011; 90: 536-544. 
9. Tracey D, Klareskog L, Sasso EH, et al. Tumor necrosis factor antagonist mechanisms of action: A comprehensive review. Pharmacol Ther 2008; 117: 244-279.

10. Grubeck-Loebenstein B, Buchan G, Chantry D, et al. Analysis of intrathyroidal cytokine production in thyroid autoimmune disease: thyroid follicular cells produce interleukin-1 alpha and interleukin-6. Clin Exp Immunol 1989; 77: 324-330.

11. Weetman AP, Rees AJ. Synergistic effects of recombinant tumour necrosis factor and interferon-gamma on rat thyroid cell growth and la antigen expression. Immunology 1988; 63: 285-289.

12. Buscema M, Todd I, Deuss U, et al. Influence of tumor necrosis factor-alpha on the modulation by interferon-gamma of HLA class II molecules in human thyroid cells and its effect on interferon-gamma binding. J Clin Endocrinol Metab 1989; 69: 433-439.

13. Weetman AP, Bright Thomas R, Freeman M. Regulation of interleukin-6 release by human thyrocytes. J Endocrinol 1990; 127: 357-361.

14. Gretzer C, Thomsen P, Jansson S, et al. Co-culture of human monocytes and thyrocytes in bicameral chamber: monocyte-derived IL-1alpha impairs the thyroid epithelial barrier. Cytokine 2000; 12: $32-40$.

15. Nilsson M, Husmark J, Bjorkman U, et al. Cytokines and thyroid epithelial integrity: interleukin-1alpha induces dissociation of the junctional complex and paracellular leakage in filter-cultured human thyrocytes. J Clin Endocrinol Metab 1998; 83: 945-952.

16. Rasmussen AK, Kayser L, Feldt Rasmussen U, et al. Influenceof tumour necrosis factor-alpha, tumour necrosis factor-beta and interferon-gamma, separately and added together with interleukin-1 beta, on the function of cultured human thyroid cells. J Endocrinol 1994; 143: 359-365.

17. Sato K, Satoh T, Shizume K, et al. Inhibition of 125 I organification and thyroid hormone release by interleukin-1, tumor necrosis factor-alpha, and interferon-gamma in human thyrocytes in suspension culture. J Clin Endocrinol Metab 1990; 70: 1735-1743.

18. Ogiwara T, Araki O, Morimura T, et al. A novel mechanism for the inhibition of type 2 iodothyronine deiodinase by tumor necrosis factor $\alpha$ : involvement of proteasomal degradation. Endocr J 2013; 60: 1035-1045.

19. Ongphiphadhanakul B, Fang SL, Tang KT, et al. Tumor necrosis factor- $\alpha$ decreases thyrotropin-induced 5 '-deiodinase activity in FRTL-5 thyroid cells. Eur J Endocrinol 1994; 130: 502-507.

20. Hershman JM, Pang XP, et al. Action of tumor necrosis factor-alpha on thyroid cells. Trans Am Clin Climatol Assoc 1994; 105: 131-144.

21. Weetman AP. Diseases associated with thyroid autoimmunity: explanations for the expanding spectrum. Clin Endocrinol (Oxf) 2011; 74: 411-418. doi: 10.1111/j.1365-2265.2010.03855.x

22. Somers EC, Thomas SL, Smeeth L, et al. Are individuals with an autoimmune disease at higher risk of a second autoimmune disorder? Am J Epidemiol 2009; 169: 749-755. doi: 10.1093/aje/kwn408

23. Cerniglia B, Judson MA. Infliximab-Induced Hypothyroidism: A Novel Case and Postulations concerning the Mechanism. Case Rep Med 2013; 2013: 216939. doi: 10.1155/2013/216939
24. Lahita RG, Vernace MA. Vasculitis, vitiligo, thyroiditis, and altered hormone levels after anti-tumor necrosis factor therapy. J Rheumatol 2011; 38: 579-580. doi: 10.3899/jrheum.100968

25. van Lieshout AW, Creemers MC, Radstake TR et al. Graves' disease in a patient with rheumatoid arthritis during treatment with anti-tumor necrosis factor-alpha. J Rheumatol 2008; 35: 938-939.

26. Allanore Y, Brémont $\mathrm{C}$, Kahan A, et al. Transient hyperthyroidism in a patient with rheumatoid arthritis treated by etanercept. Clin Exp Rheumatol 2001; 19: 356-357.

27. Caramaschi P, Biasi D, Colombatti M, et al. Anti-TNFalpha therapy in rheumatoid arthritis and autoimmunity. Rheumatol Int 2006; 26 : 209-214. doi: 10.1007/s00296-004-0542-1

28. Atzeni F, Doria A, Ghirardello A, et al. Organ-specific autoantibodies in patients with rheumatoid arthritis treated with adalimumab: a prospective long-term follow-up. Autoimmunity 2008; 41: 87-91. doi: 10.1080/08916930701620050

29. Pascart T, Ducoulombier V, Roquette D, et al. Autoimmune thyroid disorders during anti-TNF alpha therapy: coincidence, paradoxical event or marker of immunogenicity? Joint Bone Spine 2014; 81 : 369-370. doi: 10.1016/j.jbspin.2013.11.007

30. Raterman HG, Jamnitski A, Lems WF et al. Improvement of thyroid function in hypothyroid patients with rheumatoid arthritis after 6 months of adalimumab treatment: a pilot study. J Rheumatol 2011; 38: 247-251. doi: 10.3899/jrheum. 100488

31. Elkayam O, Burke M, Vardinon $\mathrm{N}$ et al. Autoantibodies profile of rheumatoid arthritis patients during treatment with infliximab. Autoimmunity 2005; 38: 155-160. doi: 10.1080/08916930400021378

32. Tarhan F, Orük G, Niflioğlu $O$ et al. Thyroid involvement in ankylosing spondylitis and relationship of thyroid dysfunction with antiTNF $\alpha$ treatment. Rheumatol Int 2013; 33: 853-857. doi: 10.1007/ s00296-012-2438-9

33. Paschou SA, Palioura E, Kothonas F, et al. The effect of anti-TNF therapy on thyroid function in patients with inflammatory bowel disease. Endocr J 2018; 65: 1121-1125. doi: 10.1507/endocrj. EJ18-0243

34. Wang ZM, Wang ZY, Lu Y. The role of cell mediated immunopathogenesis in thyroid-associated ophthalmopathy. Int J Ophthalmol 2019; 12: 1209-1214. doi: 10.18240/ijo.2019.07.24

35. Paridaens D, van den Bosch W, van der Loos T, et al. The effect of etanercept on Graves' ophthalmopathy: a pilot study. Eye 2005; 19: 1286-1289. doi: doi.org/10.1038/sj.eye.6701768

36. Boskovic O, Medenica S, Radojevic N, et al. Etanercept in the treatment of Graves' ophthalmopathy with primary hypothyroidism and rheumatoid arthritis. Cent Eur J Immunol 2019; 44: 463-465. doi: 10.5114/ceji.2019.92803

37. Komorowski J, Jankiewicz-Wika J, Siejka A, et al. Monoclonal antiTNFalpha antibody (infliximab) in the treatment of patient with thyroid associated ophthalmopathy. Klin Oczna 2007; 109: 457-460.

38. Wang Y, Patel A, Douglas RS. Thyroid Eye Disease: How A Novel Therapy May Change The Treatment Paradigm. Ther Clin Risk Manag 2019; 15: 1305-1318. doi: 10.2147/TCRM.S193018 